\title{
Oxygen and mortality in COVID-19 pneumonia: a comparative analysis of supplemental oxygen policies and health outcomes across 26 countries.
}

\author{
Goyal D, Donnelly H, Kussner A, Neil J, Bhatti S and Mansab F.
}

Daniel K Goyal, MRCP, PhD, COVID-19 Public Health Team, Public Health Gibraltar, Gibraltar \& Clinical Lecturer, University of Gibraltar, GX11 1AA Corresponding Author: daniel.goyal@gha.gi

Harry Donnelly, MBBS, Acute General Medicine, St Bernard's Hospital, Gibraltar Health Authority

Albrecht Kussner, MRCP, Emergency Medicine, St Bernard's Hospital, Gibraltar Health Authority, Gibraltar

James Neil. PhD (Computer Science). Centre for Nutrition Education and Lifestyle Management (CNELM), London, UK

Sohail Bhatti, FRSPH, Director of Public Health Gibraltar \& Head of School of Postgraduate Medicine, University of Gibraltar

Fatma Mansab, MSc Immunology, COVID-19 Public Health Team, Public Health Gibraltar \& Clinical Lecturer, University of Gibraltar 
medRxiv preprint doi: https://doi.org/10.1101/2020.07.03.20145763; this version posted July 4,2020 . The copyright holder for this preprint (which was not certified by peer review) is the author/funder, who has granted medRxiv a license to display the preprint in perpetuity.

\section{ABSTRACT}

\section{Introduction}

Hypoxia is the main cause of morbidity and mortality in COVID-19. During the COVID-19 pandemic some countries have reduced access to supplemental oxygen (e.g. oxygen rationing), whereas other nations have maintained and even improved access to supplemental oxygen. We examined whether such variation in the access to supplemental oxygen had any bearing on mortality in COVID-19.

\section{Methods}

Three independent investigators searched for, identified and extracted the nationally recommended target oxygen levels for the commencement of oxygen in COVID-19 pneumonia from the 29 worst affected countries. Mortality estimates were calculated from three independent sources. We then applied linear regression analysis to examine for potential association between national targets for the commencement of oxygen and case fatality rates.

\section{Results}

Of the 26 nations included, 15 had employed conservative oxygen strategies to manage COVID-19 pneumonia. Of them, Belgium, France, USA, Canada, China, Germany, Mexico, Spain, Sweden and the UK guidelines advised commencing oxygen when oxygen saturations (SpO2) fell to $91 \%$ or less. Target SpO2 ranged from 92\% to 95\% in the other 16 nations. Linear regression analysis demonstrated a strong inverse correlation between the national target for the commencement of oxygen and national case fatality rates (Spearman's Rho $=-0.622, \mathrm{p}<0.001$ ).

\section{Conclusion}

Our study highlights the disparity in oxygen provision for COVID-19 patients between the nations analysed, and indicates such disparity in access to supplemental oxygen may represent a modifiable factor associated with mortality during the pandemic. 
medRxiv preprint doi: https://doi.org/10.1101/2020.07.03.20145763; this version posted July 4,2020 . The copyright holder for this preprint (which was not certified by peer review) is the author/funder, who has granted medRxiv a license to display the preprint in perpetuity.

It is made available under a CC-BY 4.0 International license .

\section{Key Messages}

\section{What is already known?}

- There were no prospective clinical trials we could identify relating to COVID-19 and supplemental oxygen, nor any published studies examining access to supplemental oxygen and mortality in COVID-19.

- There are a number of studies identifying an association with low oxygen saturations at presentation and mortality in COVID-19 pneumonia.

- There is good quality evidence that a delay in the correction of hypoxia in pneumonia increases mortality.

\section{What are the new findings?}

- This study highlights the different thresholds for commencing supplemental oxygen in patients with COVID-19 across 26 nations.

- Those countries that provide better access to supplemental oxygen have a statistically significant lower mortality rate.

- Our results support the consensus view that improving access to supplemental oxygen in COVID-19 pneumonia is likely to reduce mortality. 
medRxiv preprint doi: https://doi.org/10.1101/2020.07.03.20145763; this version posted July 4, 2020. The copyright holder for this preprint (which was not certified by peer review) is the author/funder, who has granted medRxiv a license to display the preprint in perpetuity. It is made available under a CC-BY 4.0 International license.

\section{Introduction}

SARS-CoV2 causes COVID-19 (Coronavirus Disease 2019). As of May 2020, the total reported cases of COVID-19 was over 5 million, with 350,000 deaths over five months[1]. More than half these deaths have occurred in the last month. Whilst there has been a slight reduction in the rate of growth for new infections globally, this is most likely due to strict infection control policies (e.g. case-isolation, social distancing and 'lockdown')[2]. With the seroprevalence of SARS-CoV2 being reported as between $<1 \%$ to $22 \%[3]$, it is most likely the majority of infections are yet to come, and the rate of infections will once again increase as infection control measures are balanced with economic pressures.

The true COVID-19 mortality rate is difficult to ascertain during the outbreak. Background infections, asymptomatic infections, testing criteria, reporting of fatalities and the time-lag between new cases and outcome are all potential confounders[4]. This makes measuring the effects of national interventions difficult. It is though, reasonable to expect a nation's COVID-19 mortality rate will depend on access to healthcare, and likely will also depend on the type of healthcare offered. The need for effective healthcare can be reasonably inferred from the marked disparity between mortality rates during a surge of cases versus mortality post-surge[5].

Oxygen is a cornerstone of treatment for patients with COVID-19 pneumonia. Indeed, the major mechanism for injury and death in COVID-19 relates to hypoxia[6]. Despite the critical nature of oxygen therapy in COVID-19 pneumonia there remains marked variation between national guidelines for when to offer supplemental oxygen. Many nations seem to have implemented conservative oxygen strategies during the pandemic, effectively limiting the access of patients to supplemental oxygen. Others seem to have actively increased their capacity to offer supplemental oxygen for patients with COVID-19 pneumonia. Here, we examine the national guidelines from 29 nations in an effort to understand the potential impact the varying thresholds for commencing supplemental oxygen have on COVID-19 outcomes.

\section{Methods}

We followed the advice for global reporting on health estimates as per the GATHER statement[7]. All countries with more than 20,000 cases as of 18/05/20, were assessed. Three investigators independently identified the specific national recommendations for the target oxygen saturations (SpO2) to commence oxygen in patients with COVID-19. Two investigators were blinded as to the reason for the study. Each nation's ministry of health, national guideline bodies, respiratory medicine bodies and national health service were searched for relevant COVID-19 clinical guidelines. The European Society of Respiratory Medicine was a useful resource with direct links to a number of COVID-19 specific clinical guidelines from across the world. Literature databases were also used as a means of identifying links to national guidelines. If guidelines were not available in one of the languages spoken by the investigators, on-line translation services were utilised, specifically for guidelines on 'supplemental oxygen' or 'oxygen therapy' - the entire guideline was not translated. Note, only guidelines applicable to the majority of the population were extracted, and guidelines for patients with underlying conditions such as chronic obstructive airways disease were not recorded. 
medRxiv preprint doi: https://doi.org/10.1101/2020.07.03.20145763; this version posted July 4, 2020. The copyright holder for this preprint (which was not certified by peer review) is the author/funder, who has granted medRxiv a license to display the preprint in perpetuity. It is made available under a CC-BY 4.0 International license .

If guidelines were unclear, instruction was to disregard the country from further analysis. Where there were more than one recommendation the investigator was to make a determination as to the most likely guideline to be followed (figure 1). Where there was divergence between the three investigators, the consensus value was used. Results were tabulated and compared.

Case Fatality Rate and Infection Fatality Rate

Case Fatality Rate (CFR) is the percentage ratio of deaths to total cases. It is a crude figure privy to a number of potential confounders. For most nations it is likely to be numerically incorrect[4]. CFR is though, likely to maintain a relationship to actual infection mortality rate (IFR) $[3,4]$, and as such was used in this study. CFR was calculated and cross-referenced from three different sources - The WHO, John Hopkins University and Worldometer. There was no significant difference between the calculated CFR across the three sources.

\section{Patient and Public Involvement}

It was not possible to include patients or public in the present study.

\section{Statistical Analysis}

Linear regression was performed to identify a potential trend between CFR and Target SpO2, and presented using scatter-plots. Due to the sample size $(n=26)$, it was not clear whether the assumptions of normality and linearity were met, so the statistical significance of the possible relationship between CFR and target SpO2 was established using the nonparametric Spearman's-Rho test. We have also explored the effect of potentially confounding variables using the non-parametric Spearman's-rho test rather than using a parametric Mancova test to adjust for confounding, given the small sample size and uncertainty regarding linearity and normality.

\section{Results}

In total there were 29 countries with total case numbers over 20,000 on 18th May 2020. Of those, 26 countries had accessible clinical guidelines referring to target oxygen levels for the commencement of supplemental oxygen in COVID-19. UAE (United Arab Emirates) was excluded from further analysis as the national guidelines advised (at page 9) admitting all patients with COVID-19 to hospital, and commencing oxygen when 'needed'[8] - the country's low CFR is noted. The Netherlands and Belarus were also excluded due to all three investigators failing to find clear national guidelines regarding oxygen targets.

Of the remaining 26 countries there was concordance between all three investigators identifying the same national target oxygen levels in 23 countries. Of the remaining 3 countries (UK, Pakistan and Qatar), determination of national target SpO2 in COVID-19 was made by consensus. For links to national guidelines please see Supplementary File.

Of the 26 nations analysed, six recommended commencing oxygen if SpO2 fell to below 95\% (Singapore, Peru, Switzerland, Ireland, Qatar and Pakistan), five made recommendation for Below 94\% (Saudi Arabia, Chile, Brazil, India and Russia), five for 
medRxiv preprint doi: https://doi.org/10.1101/2020.07.03.20145763; this version posted July 4, 2020. The copyright holder for this preprint (which was not certified by peer review) is the author/funder, who has granted medRxiv a license to display the preprint in perpetuity.

It is made available under a CC-BY 4.0 International license .

below 93\% (Portugal, Iran, Turkey, Bangladesh and Italy), six for below 92\% (Canada, Belgium, France, UK, USA and China) and four for below 91\% (Germany, Mexico, Spain and Sweden). CFR ranged from $0.06 \%$ (Qatar) to $16.4 \%$ (Belgium). There was a strong inverse correlation between recommended target oxygen saturations and national case fatality rates $(r s=-0.622, p<0.001)$. A scatter graph with linear best-fit line is at Figure 2.

- National Case Fatality Rate

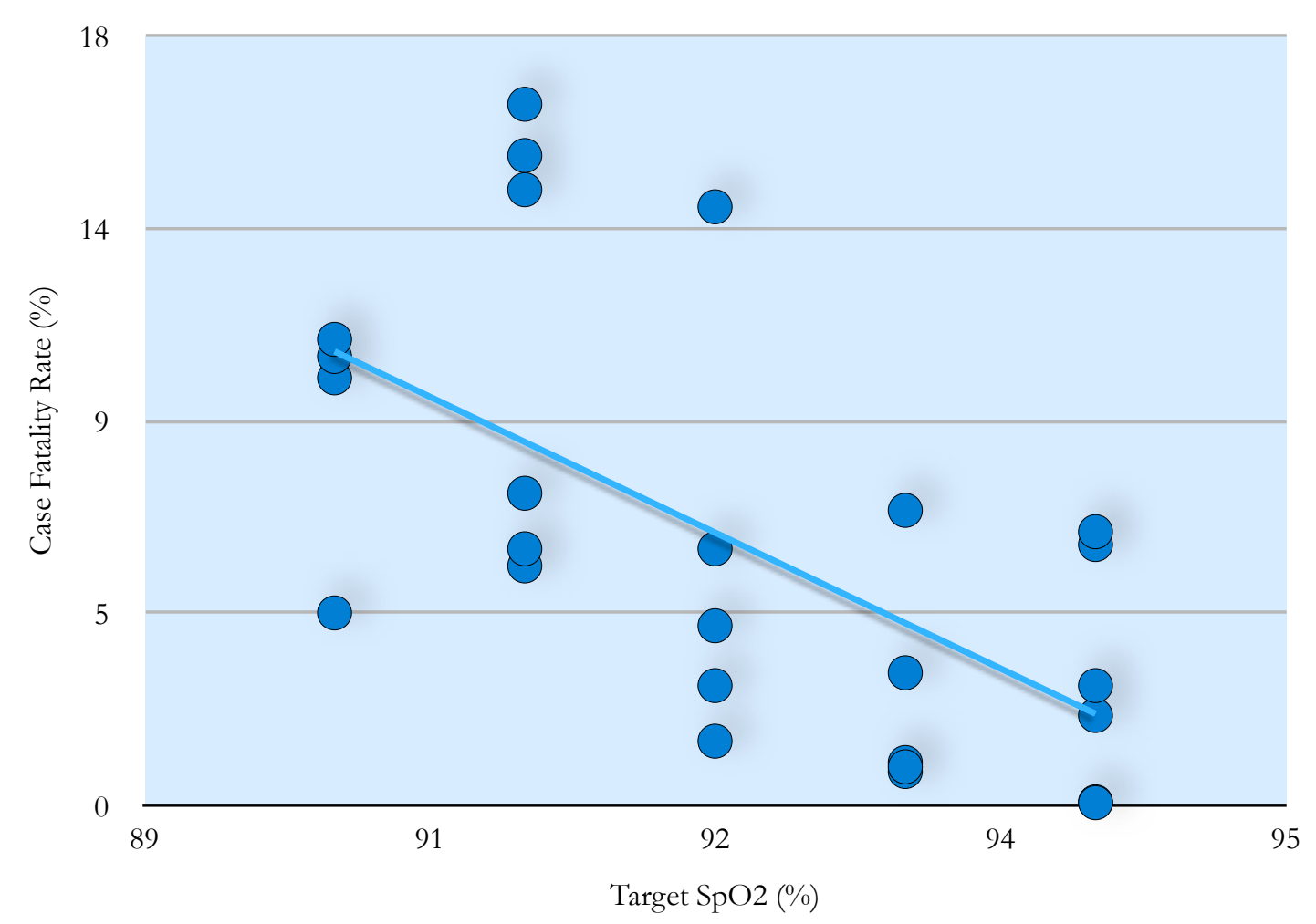

Figure 2. Scatter graph of national target oxygen saturations versus national case fatality rate with best fit linear line $(n=26)$. SpO2 - oxygen saturations.

\section{Confounders}

National guidelines for target saturations were relatively clear for most countries. Together with the high rate of consensus amongst investigators it seems unlikely that investigator bias was a significant factor. The main confounders are more likely to stem from the many variables associated with CFR.

We found no correlation between CFR and cases/million inhabitants (Figure 3B), or tests/ thousand inhabitants (Figure $3 \mathrm{C}$ ), or overall positivity rate (Figure $3 \mathrm{C}$ ), suggesting testing strategy between the countries examined did not have a significant visible relationship with our mortality measure, CFR (Table 1). We could not examine the potential impact of national-level reporting bias on the CFR from the data available. 
A

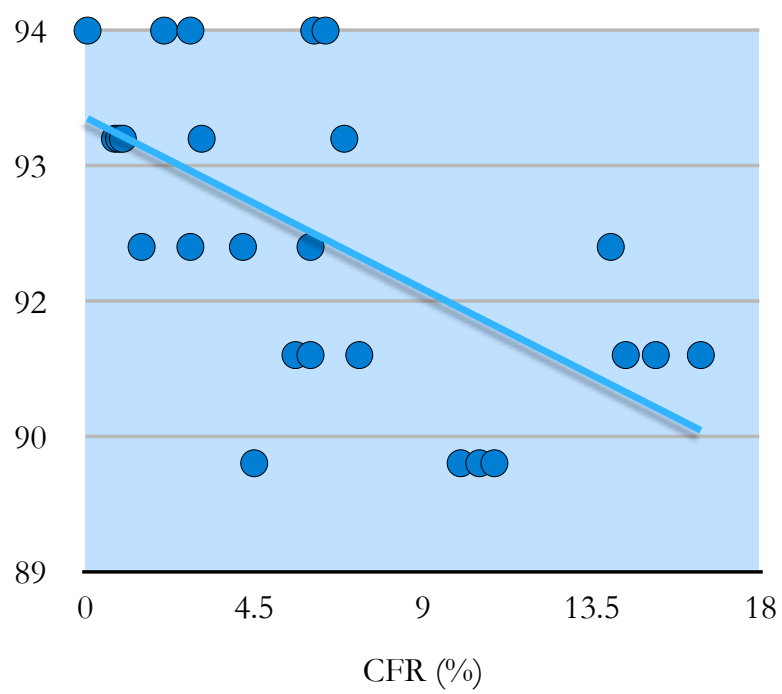

C

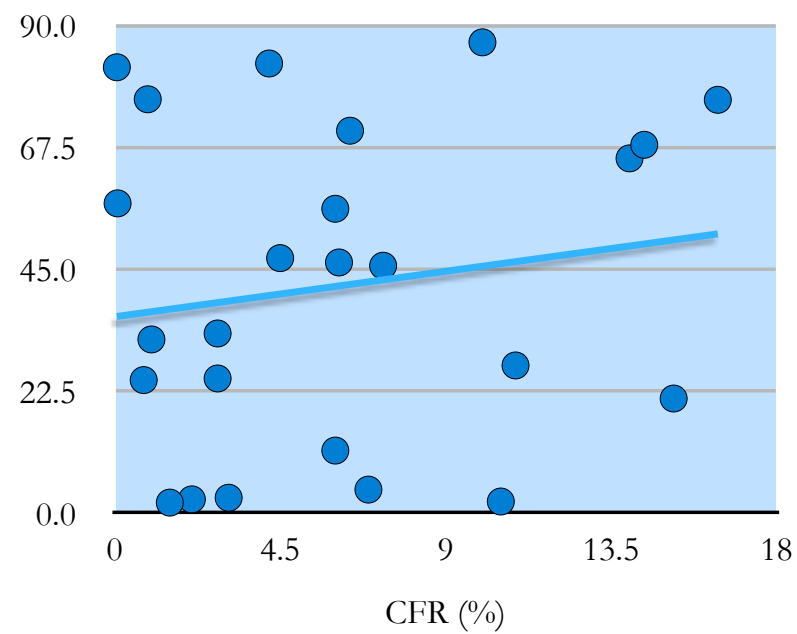

B

- Case Burden

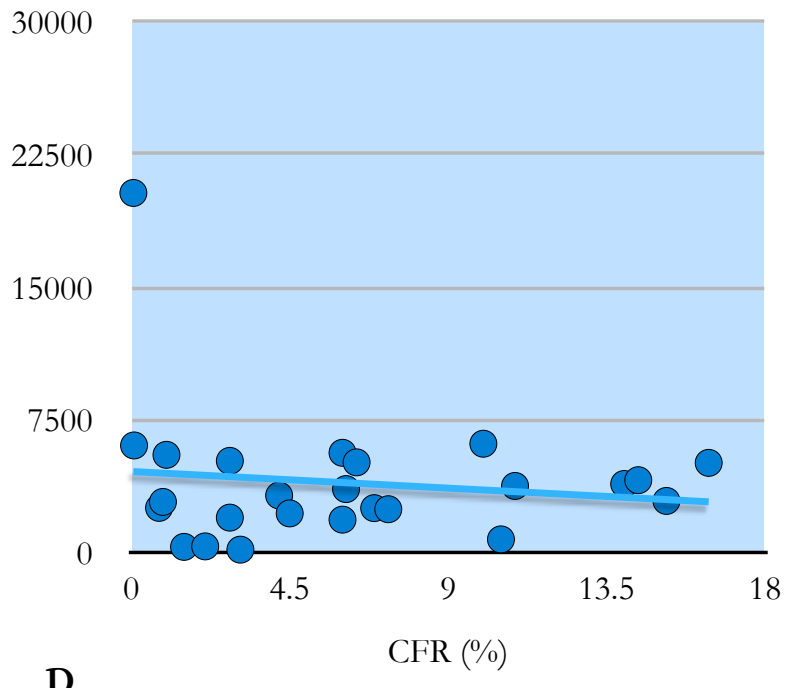

- Overall Positivity Ratio

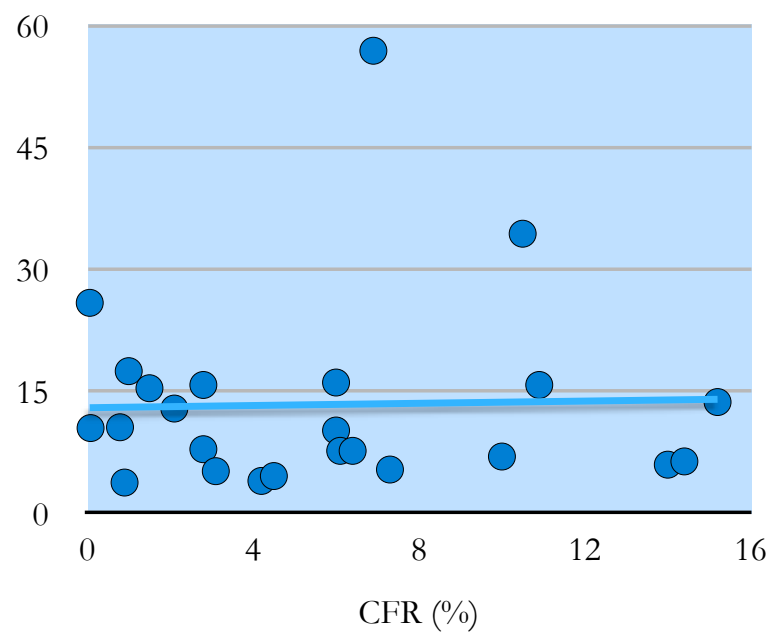

Figure 3. Scatter graphs with best-fit line for primary measure and confounders versus CFR (N= 26). CFR is along the horizontal axis in each and measured in percentage. A) Comparison of national CFR versus nationally recommended target SpO2 (\%) in COVID-19. B) CFR versus burden of cases measured by total number of cases per million. C) CFR versus Testing Rate measured by total number of tests undertaken per thousand inhabitants (tests/ thousand). D) CFR versus the overall positivity ratio (\%), measured as the percentage ratio of positive tests to total tests.

CFR - Case Fatality Rate; SpO2 - oxygen saturations. CFR - Case Fatality Rate; SpO2 Oxygen Saturations. 


$\begin{array}{ccccc}\text { SpO2 } & \begin{array}{l}\text { Tests per } \\ \text { Thousand }\end{array} & \begin{array}{l}\text { Positivity } \\ \text { Ratio }\end{array} & \text { Case Burden } & \text { CFR } \\ (\%) & & (\%) & \begin{array}{l}\text { (cases/ } \\ \text { million) }\end{array} & (\%)\end{array}$

\begin{tabular}{|c|c|c|c|c|c|}
\hline Qatar & 94 & 82.3 & 25.9 & 20311 & 0.06 \\
\hline Singapore & 94 & 57.2 & 10.5 & 6036 & 0.08 \\
\hline Pakistan & 94 & 2.6 & 12.9 & 329 & 2.1 \\
\hline Peru & 94 & 33.2 & 15.8 & 5163 & 2.8 \\
\hline Switzerland & 94 & 46.3 & 7.7 & 3569 & 6.1 \\
\hline Ireland & 94 & 70.6 & 7.7 & 5080 & 6.4 \\
\hline Saudi Arabia & 93 & 24.6 & 10.6 & 2506 & 0.79 \\
\hline Russia & 93 & 76.4 & 3.8 & 2843 & 0.9 \\
\hline Chile & 93 & 32.1 & 17.5 & 5505 & 1 \\
\hline India & 93 & 2.9 & 5.2 & 144 & 3.1 \\
\hline Brasil & 93 & 4.4 & 56.9 & 2492 & 6.9 \\
\hline Bangledesh & 92 & 2.0 & 15.4 & 301 & 1.5 \\
\hline Turkey & 92 & 24.9 & 7.9 & 1955 & 2.8 \\
\hline Portugal & 92 & 83.0 & 4 & 3206 & 4.2 \\
\hline Iran & 92 & 11.6 & 16.1 & 1841 & 6 \\
\hline Italy & 92 & 65.5 & 6 & 3857 & 14 \\
\hline China & 91 & $\mathrm{~N} / \mathrm{A}$ & $\mathrm{N} / \mathrm{A}$ & $\mathrm{N} / \mathrm{A}$ & 5.6 \\
\hline USA & 91 & 56.2 & 10.2 & 5620 & 6 \\
\hline Canada & 91 & 45.7 & 5.4 & 2431 & 7.3 \\
\hline UK & 91 & 68.0 & 6.4 & 4072 & 14.4 \\
\hline France & 91 & 21.2 & 13.7 & 2899 & 15.2 \\
\hline Belgium & 91 & 76.3 & 6.7 & 5051 & 16.4 \\
\hline Germany & 90 & 47.1 & 4.6 & 2194 & 4.5 \\
\hline Spain & 90 & 86.9 & 7 & 6133 & 10 \\
\hline Mexico & 90 & 2.2 & 34.4 & 725 & 10.5 \\
\hline Sweden & 90 & 27.3 & 15.8 & 3746 & 10.9 \\
\hline $\begin{array}{l}\text { Correlation with CFR } \\
\text { (Spearman's Ro) }\end{array}$ & -0.622 & 0.0658 & -0.13 & 0.018 & \\
\hline 2-tailed (p-value) & $<0.001$ & 0.75 & 0.54 & 0.93 & \\
\hline
\end{tabular}

Table 1. National CFR, target SpO2 and potential testing confounders in 26 countries. CFR - Case Fatality Rate; SpO2 - Oxygen Saturations. Overall Positivity Ratio- percentage ratio of positive to total cases; Case Burden - total number of positive cases per million inhabitants. Data extracted from WHO, Worldometer and John Hopkins University. 
medRxiv preprint doi: https://doi.org/10.1101/2020.07.03.20145763; this version posted July 4, 2020. The copyright holder for this preprint (which was not certified by peer review) is the author/funder, who has granted medRxiv a license to display the preprint in perpetuity. It is made available under a CC-BY 4.0 International license .

\section{Discussion}

National guidelines for when to commence supplemental oxygen in patients with COVID-19 varied significantly between the countries examined. Combined, the target $\mathrm{SpO} 2$ for the commencement of oxygen and target $\mathrm{SpO} 2$ for ongoing treatment varied from $90 \%$ to $98 \%$. Countries that implemented conservative oxygen strategies in response to the pandemic - effectively limiting access to supplemental oxygen - had statistically significant higher case fatality rates. There are a number of potential reasons for the variation in oxygen policies between countries and the association with mortality.

\section{Causative effect}

It has been established that a delay in identifying and correcting hypoxia in pneumonia leads to increased disease severity, increased rate of mechanical ventilation and increased mortality[9,10]. Whilst there are no controlled studies in COVID-19 specifically examining duration spent hypoxic and subsequent disease burden and mortality, Sun et al., has reported a reduction in the need for mechanical ventilation where hypoxia was detected and corrected early in patients with COVID-19[11].

In relation to conservative oxygen strategies generally, there are four key mortality studies. The IOTA meta-analysis published in 2018 examined conservative versus liberal oxygen strategies across a range of studies. Whilst none of the studies analysed in the IOTA metaanalysis related to pneumonia, and the majority of studies examined oxygen as a treatment not as a means to correct hypoxia, the authors suggest optimal target SpO2 for all acute medical patients might be 94-96\%[12].

Since the IOTA study, there have been three clinical studies, two of which were randomised controlled trials (RCT), examining the mortality effect of conservative oxygen. The ICU-ROX trial suggests there may be no mortality effect at the higher target levels of SpO2 (96-97\% versus 95-96\%) in mechanically ventilated patients from any cause $(n=1000)[13]$. Another, retrospective analysis, published in March 2020 examined over 35,000 intensive care patients and found the optimum SpO2 target of $94-98 \%$. The authors note that patients who were in the optimal range for only $40 \%$ of the time had nearly twice the mortality of those who spent $80 \%$ of the time within the optimal target[14].

The most recent RCT, and the most well-controlled study of true conservative oxygen strategies to date (and the most relevant to COVID-19), examined 204 patients with acute respiratory distress syndrome (ARDS). Patients were randomised to either a conservative arm (actual SpO2 of 92-93\%) versus a liberal arm (SpO2 of 95-97\%), and then followed up for 90 days. The study was halted early due to excessive deaths in the conservative oxygen group, with a $27 \%$ increase in intensive care deaths and a $50 \%$ increase in 90 day mortality[15].

Based on our current understanding of the affects of hypoxia on inflammation[16] and coagulation[17], there is good scientific basis for the increased mortality associated with sub-optimal oxygen strategies and/or a delay in correcting hypoxia. There are direct effects of hypoxia leading to increased mortality, such as cardiac arrhythmias and ischaemic related pathologies (as identified in the aforementioned ARDS study[15]). It is also quite plausible, indeed quite likely, given that hypoxia is pro-inflammatory, the delay in correcting hypoxia leads to more severe disease. This of course raises the possibility that rationing, or a conservative oxygen approach, or a failure to provide access to supplemental oxygen in COVID-19 pneumonia, actually increases healthcare burden and resource consumption. 
medRxiv preprint doi: https://doi.org/10.1101/2020.07.03.20145763; this version posted July 4, 2020. The copyright holder for this preprint (which was not certified by peer review) is the author/funder, who has granted medRxiv a license to display the preprint in perpetuity. It is made available under a CC-BY 4.0 International license .

Whilst sometimes arguably unavoidable, the decision to limit access to supplemental oxygen should be undertaken mindful of the likely mortality impact, and of the possibility of perpetuating a healthcare crisis. Implementing oxygen early is likely to prevent disease progression, as suggested by Sun et al. [11], and as is consistent with established practice relating to pneumonia generally $[9,10]$.

\section{Resource limitations}

For some nations there was a resource limitation issue, or at least a fear of resource limitation, with secondary implementation of conservative oxygen strategies. For example, the UK directive to ration oxygen supply in April 2020 reduced the normal national target for the commencement of oxygen from $\mathrm{SpO} 2$ of $94 \%$ to a new value of $91 \%$. The reason for rationing was related to the surge of infections and subsequent concern over the supply of oxygen[18]. If such practises are common in other nations, the relationship between national guidelines' $\mathrm{SpO} 2$ and national CFR identified here may be a representation of the demands on healthcare during a surge of COVID-19 cases.

There are a number of reasons why mortality increases during a surge of infections. Patients are less likely to attend hospital or seek medical care, either for fear of contracting COVID-19 or over-burdening their health service[19]. Triage systems during a surge can be set with high thresholds for onward referrals[20]. Another mortality factor is a potential lack of resources both staff and consumables. The overall delay to treatment that ensues prevents early correction of hypoxia, implementation of VTE (venous thromboembolism) prophylaxis, readjustment of medications (e.g. nephrotoxics) and the detection of secondary bacterial infection, and thus a likely increased mortality[21]

So then, the association between target $\mathrm{SpO} 2$ and CFR identified here may be more related to target $\mathrm{SpO} 2$ being an indicator of an overwhelmed healthcare service. If this is the case, a lower than usual target $\mathrm{SpO} 2$ may still contribute to the higher mortality experienced in nations that suffered an overwhelming surge. In a UK cohort, during the initial surge of infections, and during oxygen rationing, approximately $62 \%$ of patients presented hypoxic, and of those that died $75 \%(60 / 80)$ of patients presented hypoxic (defined broadly in this study as $\mathrm{SpO} 2<95 \%$ )[22]. In a cohort from Mexico, 96\% of the patients who died presented with $\mathrm{SpO} 2$ under 88\%[23].

Part of the increased mortality seen during a surge of infections may be related to the secondary conservative oxygen policies and delay in correction of hypoxia.

\section{National Approach}

The issuing of national guidelines recommending lower target oxygen saturations than would be typical for viral pneumonias[24], may relate more to the overall approach of a national response to COVID-19, and as such, it is this 'national approach' that relates to mortality rate.

All three investigators noted the quite different approaches between nations, as set out in their national guidelines. Some followed a 'stay home' approach, whereas others defaulted to clinical assessment of patients either with COVID-19 or with any risk factor associated with it. For example, Singapore guidelines default to clinical assessment[25], whereas a country with a similar prevalence burden, the UK, has much higher thresholds for referral onward for assessment[26] (Table 2). 
medRxiv preprint doi: https://doi.org/10.1101/2020.07.03.20145763; this version posted July 4, 2020. The copyright holder for this preprint (which was not certified by peer review) is the author/funder, who has granted medRxiv a license to display the preprint in perpetuity.

It is made available under a CC-BY 4.0 International license .

Singapore

Criteria for Clinical Assessment

$\mathrm{SpO} 2(\%)$

Age (yrs)

Co-morbidity

Duration of illness (days)

Epidemiology

Cases/million inhabitants

Physicians/10,000 head of capita

CFR $(\%)$

\section{$<95$}

$>65$

Any

$>3$

6,063

24

0.08
UK

$<92$

Irrelevant

Severe

Irrelevant

4,076

28

13.4

Table 2. Comparison of the Criteria for Assessment in suspected or confirmed COVID-19 between Singapore and the UK. Information is based on the clinical guidelines from each nation and WHO (see Supplementary File). SpO2 - oxygen saturations. CFR - case fatality rate.

In this situation, where the national guideline target SpO2 is part of an overall strategy of avoiding admissions, then whilst it does remain likely conservative oxygen approaches do contribute to higher mortality, there may also be contribution of other policies. In the UK versus Singapore example, a target SpO2 of less than $92 \%$ is likely to be harmful, but equally, failing to account for age of the patient or duration of fever may also be harmful. As such, the relationship identified here between CFR and target SpO2 may be more a relationship between CFR and national strategy. Target SpO2 may be more of an indicator of national policy.

\section{Limitations}

This study highlights the variation in national guidelines for when to commence supplemental oxygen in patients with COVID-19. In of itself, this raises important questions as to the optimal response to COVID-19. Attempting to delineate the interventions and strategies that are potentially beneficial between nations is difficult without using a mortality estimation, which carries inherent confounders. CFR depends on many factors, not least of which is the accurate reporting of COVID-19 related deaths. Whilst we found no correlation between CFR and rates of testing or crude case burden, we could not account for disparities in reporting of deaths. We were aware of this limitation prior to the study, but agreed with the view that while CFR is unlikely to be numerically correct, the difference between countries will remain[3,4], and as such the association is likely to be accurate.

We undertook an analysis of the national guidelines using three independent investigators. The consensus amongst the investigators supports the accuracy of the target SpO2 
medRxiv preprint doi: https://doi.org/10.1101/2020.07.03.20145763; this version posted July 4, 2020. The copyright holder for this preprint (which was not certified by peer review) is the author/funder, who has granted medRxiv a license to display the preprint in perpetuity. It is made available under a CC-BY 4.0 International license .

extracted. The possibility remains that localities within a country, or individual doctors and nurses, chose not to follow their national guidelines. Even if such local differences were significant, the national guidelines permits not implementing oxygen therapy until the target oxygen level is reached, therefore triage systems, nurses and physicians can avoid admissions, and thus limit access to supplemental oxygen. Despite the prospect of local variations in following the guidelines, the presence of the guidelines will shape and likely reflect practice nationally.

\section{Conclusion}

There is clear disparity between national guidelines for target oxygen saturations (SpO2) in COVID-19 across the countries analysed here, and such disparity is associated with national case fatality rates (CFR). Whilst there are multiple confounders to the CFR, the overall relationship between increasing CFR with a decreasing target SpO2 is likely real. The cause for the relationship may be a true causative effect of hypoxia on mortality. It may also be an indirect effect of delayed or reduced access to supplemental oxygen stemming from an overwhelmed or under-resourced health service, or, a similar policyrelated reduction in access to supplemental oxygen associated with the differing overall national approaches to COVID-19 - stay home versus clinical assessment. All three possibilities highlighted here implicate delayed initiation of oxygen in the excess mortality associated with COVID-19.

Further research is needed to explore the population risk associated with delayed correction of hypoxia in COVID-19. Additionally, it would be useful to undertake a healthrisk analysis, from a resource allocation perspective, on the benefits of increasing access to supplemental oxygen for patients with COVID-19 versus other interventions. As it stands currently, our results support the position that managing COVID-19 pneumonia should not differ from the management of other pneumonias, in so much as, access to supplemental oxygen is necessary to prevent excessive mortality.

\section{Conflicts}

The authors declare no conflicts of interests

\section{Contribution}

$\mathrm{DG}, \mathrm{HD}, \mathrm{AK}, \mathrm{JN}, \mathrm{SB}$ and FB contributed to the conception and/or design of the study and contributed to the manuscript. DG, HD and FB conducted the analysis of the national guidelines. Statistical analysis was undertaken primarily by JN. DG wrote the majority of the manuscript. SB and FB undertook final edits. All contributors reviewed the final manuscript before submission. 
medRxiv preprint doi: https://doi.org/10.1101/2020.07.03.20145763; this version posted July 4, 2020. The copyright holder for this preprint (which was not certified by peer review) is the author/funder, who has granted medRxiv a license to display the preprint in perpetuity. It is made available under a CC-BY 4.0 International license .

\section{REFERENCES}

1. WHO Situation Report 119, May 18th 2020. https://www.who.int/docs/default-source/ coronaviruse/situation-reports/20200518-covid-19-sitrep-119.pdf?sfvrsn=4bd9de25 4

2. Okell LC, Verity R, Watson OJ, et al. Have deaths from COVID-19 in Europe plateaued due to herd immunity? [published online ahead of print, 2020 Jun 11]. Lancet. 2020;395(10241):e110e111. doi:10.1016/S0140-6736(20)31357-X

3. Ioannidis J. The infection fatality rate of COVID-19 inferred from seroprevalence data. medRxiv 2020.05.13.20101253; doi: https://doi.org/10.1101/2020.05.13.20101253 PREPRINT - Not Peer reviewed.

4. Battegay M, Kuehl R, Tschudin-Sutter S, Hirsch HH, Widmer AF, Neher RA. 2019-novel Coronavirus (2019-nCoV): estimating the case fatality rate - a word of caution. Swiss Med Wkly. 2020;150:w20203. Published 2020 Feb 7. doi:10.4414/smw.2020.20203

5. Ji Y, Ma Z, Peppelenbosch MP, Pan Q. Potential association between COVID-19 mortality and health-care resource availability. Lancet Glob Health. 2020;8(4):e480. doi:10.1016/ S2214-109X(20)30068-1

6. Zhou F, Yu T, Du R, et al. Clinical course and risk factors for mortality of adult inpatients with COVID-19 in Wuhan, China: a retrospective cohort study [published correction appears in Lancet. 2020 Mar 28;395(10229):1038] [published correction appears in Lancet. 2020 Mar]

7. Stevens GA, Alkema L, Black RE, et al. Guidelines for Accurate and Transparent Health Estimates Reporting: the GATHER statement. Lancet. 2016;388(10062):e19-e23. doi:10.1016/ S0140-6736(16)30388-9

8. United Arab Emirates Ministry of Health and Prevention. National Guidelines for Clinical Management and Treatment of COVID-19. April 3rd, 2020, Version 2. https://www.dha.gov.ae/ en/HealthRegulation/Documents/ COVID\%20National\%20Guidelines\%20FINAL\%2018\%20March.pdf

9. Hu WP, Zhang FY, Zhang J, et al. Initial diagnosis and management of adult communityacquired pneumonia: a 5-day prospective study in Shanghai. J Thorac Dis. 2020;12(4): 1417-1426. doi:10.21037/jtd.2020.03.02

10. Blot SI, Rodriguez A, Solé-Violán J, et al. Effects of delayed oxygenation assessment on time to antibiotic delivery and mortality in patients with severe community-acquired pneumonia. Crit Care Med. 2007;35(11):2509-2514. doi:10.1097/01.CCM.0000287587.43801.9C

11. Sun Q, Qiu H, Huang M, Yang Y. Lower mortality of COVID-19 by early recognition and intervention: experience from Jiangsu Province. Ann Intensive Care. 2020;10(1):33. Published 2020 Mar 18. doi:10.1186/s13613-020-00650-2

12. O'Driscoll BR, Howard LS, Earis J, Mak V; British Thoracic Society Emergency Oxygen Guideline Group; BTS Emergency Oxygen Guideline Development Group. BTS guideline for oxygen use in adults in healthcare and emergency settings. Thorax. 2017;72(Suppl 1):ii1-ii90. doi:10.1136/thoraxjnl-2016-209729

13. Chu DK, Kim LH, Young PJ, et al. Mortality and morbidity in acutely ill adults treated with liberal versus conservative oxygen therapy (IOTA): a systematic review and meta-analysis. Lancet. 2018;391(10131):1693-1705. doi:10.1016/S0140-6736(18)30479-3

14. Van den Boom W, Hoy M, Sankaran J, et al. The Search for Optimal Oxygen Saturation Targets in Critically III Patients: Observational Data From Large ICU Databases. Chest. 2020;157(3):566-573. doi:10.1016/j.chest.2019.09.015

15. Barrot L, Asfar P, Mauny F, et al. Liberal or Conservative Oxygen Therapy for Acute Respiratory Distress Syndrome. N Engl J Med. 2020;382(11):999-1008. doi:10.1056/NEJMoa1916431

16. Fröhlich S, Boylan J, McLoughlin P. Hypoxia-induced inflammation in the lung: a potential therapeutic target in acute lung injury?. Am J Respir Cell Mol Biol. 2013;48(3):271-279. doi: 10.1165/rcmb.2012-0137TR

17. Børvik T, Evensen LH, Morelli VM, Melbye H, Brækkan SK, Hansen JB. Impact of respiratory symptoms and oxygen saturation on the risk of incident venous thromboembolism-the Troms $\varnothing$ study. Res Pract Thromb Haemost. 2020;4(2):255-262. Published 2020 Jan 9. doi:10.1002/ rth2.12299

18. NHS England. Clinical guide for the optimal use of Oxygen therapy during the coronavirus pandemic. 9 April 2020 Version 1. https://www.england.nhs.uk/coronavirus/wp-content/uploads/ sites/52/2020/04/C0256-specialty-guide-oxygen-therapy-and-coronavirus-9-april-2020.pdf 
medRxiv preprint doi: https://doi.org/10.1101/2020.07.03.20145763; this version posted July 4, 2020. The copyright holder for this preprint (which was not certified by peer review) is the author/funder, who has granted medRxiv a license to display the preprint in perpetuity. It is made available under a CC-BY 4.0 International license .

19. Lee SA, Mathis AA, Jobe MC, Pappalardo EA. Clinically significant fear and anxiety of COVID-19: A psychometric examination of the Coronavirus Anxiety Scale [published online ahead of print, 2020 May 20]. Psychiatry Res. 2020;290:113112. doi:10.1016/j.psychres. 2020.113112

20. Steinberg E, Balakrishna A, Habboushe J, Shawl A, Lee J. Calculated decisions: COVID-19 calculators during extreme resource-limited situations. Emerg Med Pract. 2020;22(4 Suppl):CD1-CD5. Published 2020 Apr 6.

21. Goyal DK, Mansab F, Iqbal A, Bhatti S. Early intervention likely improves mortality in COVID-19 infection [published online ahead of print, 2020 May 1]. Clin Med (Lond). 2020;clinmed. 2020-0214. doi:10.7861/clinmed.2020-0214

22. Kenneth F. Baker, Aidan T. Hanrath, Ina Schim van der Loeff et al., COVID-19 management in a UK NHS Foundation Trust with a High Consequence Infectious Diseases centre: a detailed descriptive analysis medRxiv 2020.05.14.20100834; https://doi.org/ 10.1101/2020.05.14.20100834. PREPRINT - not peer reviewed yet.

23. Soto-Mota, Braulio A. Marfil Garza, Erick Martinez Rodriguez et al., The Low-HARM score for predicting mortality in patients diagnosed with COVID-19: a multicentre validation study. medRxiv 2020.05.26.20111120 https://doi.org/10.1101/2020.05.26.20111120 PREPRINT - not peer reviewed yet.

24. British Thoracic Society 2015 - Annotated BTS Guideline for the management of CAP in adults (2009). https://www.brit-thoracic.org.uk/quality-improvement/guidelines/pneumonia-adults/

25. National Centre for Infectious Diseases (Singapore), Interim Treatment Guidelines for COVID-19 (Version 1.0, dated 2 April 2020) https://www.ncid.sg/Health-Professionals/ Diseases-and-Conditions/Documents/ Treatment\%20Guidelines\%20for\%20COVID-19\%20\%282\%20Apr\%202020\%29\%20-final.pdf

26. NICE (UK) guideline [NG165] COVID-19 rapid guideline: managing suspected or confirmed pneumonia in adults in the community Published date: 03 April 2020 - https://www.nice.org.uk/ guidance/ng165 
medRxiv preprint doi: https://doi.org/10.1101/2020.07.03.20145763; this version posted July 4,2020 . The copyright holder for this preprint (which was not certified by peer review) is the author/funder, who has granted medRxiv a license to display the preprint in perpetuity.

It is made available under a CC-BY 4.0 International license .

\title{
Supplementary File
}

\section{Oxygen and mortality in COVID-19 pneumonia: a comparative analysis of supplemental oxygen policies and health outcomes across 26 countries.}

\author{
Goyal D, et al.,
}

\begin{tabular}{|c|c|c|}
\hline & $\begin{array}{l}\text { Target } \\
\text { O2 } \\
\text { Sats }\end{array}$ & $\begin{array}{l}\text { Link to National Guidelines } \\
\text { All viewed between 18th May } 2020 \text { and 6th June } 2020\end{array}$ \\
\hline Pakistan & $94 \%$ & $\begin{array}{l}\text { Government of Pakistan - guidelines for all patients with COVID-19 } \\
\text { http://covid.gov.pk/new_guidelines/ } \\
\text { 05June2020_20200106_Clinical_Management_Guidelines_for_COVID-19_infection_v2.pdf }\end{array}$ \\
\hline Singapore & $94 \%$ & $\begin{array}{l}\text { National Centre for Infectious Diseases, Singapore - guidelines for all patients with COVID-19 } \\
\text { https://www.ncid.sg/Health-Professionals/Diseases-and-Conditions/Documents/ } \\
\text { Treatment } \% 20 \text { Guidelines } \% 20 \text { for } \% 20 \text { COVID-19\%20\%282\%20Apr\%202020\%29\%20-final.pdf }\end{array}$ \\
\hline Swiss & $94 \%$ & $\begin{array}{l}\text { Swiss Society of Intensive Care, published in Swiss Medical Weekly DOI: https://doi.org/10.4414/ } \\
\text { smw.2020.20227 } \\
\text { Publication Date: } 24.03 .2020 \\
\text { Applies to all adult patients with COVID-19 } \\
\text { https://smw.ch/article/doi/smw.2020.20227 }\end{array}$ \\
\hline Ireland & $94 \%$ & $\begin{array}{l}\text { Irish Thoracic Society. } \\
\text { https://irishthoracicsociety.com/wp-content/uploads/2020/03/COVID-Respiratory-Management- } \\
\text { Guideline09.04.20.pdf }\end{array}$ \\
\hline Qatar & $94 \%$ & $\begin{array}{l}\text { Ministry of Public Health, Qatar } \\
\text { https://ddc.moph.go.th/viralpneumonia/eng/file/guidelines/g_CPG.pdf }\end{array}$ \\
\hline Saudi Arabia & $93 \%$ & $\begin{array}{l}\text { Ministry of Health, Kingdom of Saudi Arabia } \\
\text { https://www.moh.gov.sa/Ministry/MediaCenter/Publications/Documents/Coronavirus-Disease-2019- } \\
\text { Guidelines-v1.2.pdf }\end{array}$ \\
\hline Chile & $93 \%$ & $\begin{array}{l}\text { RECOMENDACIONES CLÍNICAS DE } \\
\text { KINESIOLOGÍA RESPIRATORIA EN ATENCIÓN DE } \\
\text { PACIENTES CON COVID-19 } \\
\text { Sociedad Chilena de Kinesiología Respiratoria (SOCHIKIR) } \\
\text { Sociedad Argentina de Kinesiología Cardio Respiratoria (SAKICARE) } \\
\text { División de Kinesiología Intensiva, Sociedad Chilena de Medicina Intensiva (DIKISOCHIMI) } \\
\text { https://www.researchgate.net/publication/ } \\
\underline{340608875 \text { Guia_de recomendaciones_clinicas_de kinesiologia_respiratoria_en_atencion_de_paci }}\end{array}$ \\
\hline India & $93 \%$ & $\begin{array}{l}\text { INTERNATIONAL PULMONOLOGIST'S CONSENSUS ON COVID-19 } \\
\text { https://www.unah.edu.hn/dmsdocument/9674-consenso-internacional-de-neumologos-sobre- } \\
\text { covid-19-version-ingles }\end{array}$ \\
\hline Portugal & $92 \%$ & $\begin{array}{l}\text { SOCIEDADE PORTUGUESA DE PNEUMOLOGIA } \\
\text { RECOMENDAÇÕES DA SPP SOBRE TERAPIAS RESPIRATÓRIAS NÃO-INVASIVAS EM } \\
\text { CONTEXTO DE DOENTE AGUDO/CRÓNICO AGUDIZADO NA COVID-19 } \\
\text { https://www.sppneumologia.pt/uploads/subcanais_conteudos_ficheiros/terapias_spp.pdf }\end{array}$ \\
\hline
\end{tabular}


medRxiv preprint doi: https://doi.org/10.1101/2020.07.03.20145763; this version posted July 4,2020 . The copyright holder for this preprint (which was not certified by peer review) is the author/funder, who has granted medRxiv a license to display the preprint in perpetuity.

It is made available under a CC-BY 4.0 International license.

\begin{tabular}{|c|c|c|}
\hline & $\begin{array}{l}\text { Target } \\
\text { O2 } \\
\text { Sats }\end{array}$ & $\begin{array}{l}\text { Link to National Guidelines } \\
\text { All viewed between 18th May } 2020 \text { and 6th June } 2020\end{array}$ \\
\hline Turkey & $92 \%$ & $\begin{array}{l}\text { Turkey Ministry of Health } \\
\text { COVID-19 (SARS-CoV2 ENFEKSIYONU) REHBERİ, March } 2020 \\
\text { https://covid19bilgi.saglik.gov.tr/depo/rehberler/COVID-19_Rehberi.pdf. Page } 23\end{array}$ \\
\hline Italy & $92 \%$ & $\begin{array}{l}\text { Italian Thoracic Society (AIPO - ITS) and Italian Respiratory Society (SIP/IRS), March } 2020 \\
\text { AIPO Managing the Respiratory care of patients with COVID-19.pdf } \\
\text { https://ers.app.box.com/s/j09ysr2kdhmkcu1ulm8y8dxnosm6yi0h }\end{array}$ \\
\hline UK & $91 \%$ & $\begin{array}{l}\text { 1. NHS England. Clinical guide for the optimal use of Oxygen therapy during the coronavirus } \\
\text { pandemic. } 9 \text { April } 2020 \text { Version } 1 \text {. https://www.england.nhs.uk/coronavirus/wp-content/uploads/ } \\
\text { sites/52/2020/04/C0256-specialty-guide-oxygen-therapy-and-coronavirus-9-april-2020.pdf } \\
\text { 2. National Institute of Clinical Guidelines, UK - } \underline{\text { https://www.nice.org.uk/guidance/ng165 }}\end{array}$ \\
\hline Belgium & $91 \%$ & $\begin{array}{l}\text { Institute of Tropical medicine Antwerp } \\
\text { INTERIM CLINICAL GUIDANCE FOR ADULTS WITH SUSPECTED OR CONFIRMED } \\
\text { COVID-19 IN BELGIUM } \\
\text { Accessed 20/05/20 } \\
\text { https://covid-19.sciensano.be/sites/default/files/Covid19/ } \\
\text { COVID-19_InterimGuidelines_Treatment_ENG.pdf }\end{array}$ \\
\hline France & $91 \%$ & $\begin{array}{l}\text { Pneumology and Respiratory Intensive Care Department, Dijon University Hospital Center, Dijon, } \\
\text { France } \\
\text { Procedure for the pulmonary management of non-ICU patients hospitalized in the context of the } \\
\text { COVID-19 pandemic } \\
\text { http://splf.fr/wp-content/uploads/2020/04/RespiPreREA-SPLF-GAVO2avril2020-english-version- } \\
\text { r.pdf }\end{array}$ \\
\hline Canada & $91 \%$ & $\begin{array}{l}\text { Government of Canada } \\
\text { Clinical management of patients with moderate to severe COVID-19 - Interim guidance } \\
\text { https://www.canada.ca/en/public-health/services/diseases/2019-novel-coronavirus-infection/clinical- } \\
\text { management-covid-19.html\#5 }\end{array}$ \\
\hline Peru & $94 \%$ & $\begin{array}{l}\text { Society of Pneumologia, Peru } \\
\text { Lineamientos de manejo hospitalario del paciente con COVID-19, 28.MARZO.2020. http:// } \\
\text { www.spneumologia.org.pe https://drive.google.com/file/d/ } \\
\text { 1VQk7Vo8mlJ4ilMekFzsW4rUOPIRy-8wX/view }\end{array}$ \\
\hline Brasil & $93 \%$ & $\begin{array}{l}\text { GRUPO FORÇA COLABORATIVA COVID-19 BRASIL } \\
\text { Orientações sobre Diagnóstico, Tratamento e Isolamento de Pacientes com COVID-19. } \\
\text { Versão } 01 \text { Data:13/04/2020 }\end{array}$ \\
\hline Germany & $90 \%$ & $\begin{array}{l}\text { German Society of Medical Intensive Care and Emergency Medicine } \\
\text { German recommendations for critically ill patients with COVID-19 } \\
\text { https://pneumologie.de/fileadmin/user_upload/COVID-19/ } \\
\text { German_recommendations_for_critically_ill_patients_with_COVID-19._MKIM_2019.pdf }\end{array}$ \\
\hline Iran & $92 \%$ & $\begin{array}{l}\text { Health and Treatment Deputy of the Ministry of Health and Medical Education (2020). Guideline } \\
\text { for the diagnosis and treatment of COVID-19 in outpatients and inpatients. http:// } \\
\text { dme.behdasht.gov.ir/uploads/Felo_Tashkish.pdf }\end{array}$ \\
\hline Bangladesh & $92 \%$ & $\begin{array}{l}\text { Disease Control Division } \\
\text { Directorate General of Health Services Ministry of Health \& Family Welfare Government of the } \\
\text { People's Republic of Bangladesh } \\
\text { National Guidelines on Clinical Management of Coronavirus Disease } 2019 \text { (Covid-19) Version } 4.0 \\
30 \text { March } 2020 \\
\text { http://www.mohfw.gov.bd/index.php? } \\
\text { option=com_docman\&task=doc_download\&gid=22424\&lang=en. }\end{array}$ \\
\hline China & $91 \%$ & $\begin{array}{l}\text { Jin YH, Cai L, Cheng ZS, et al. A rapid advice guideline for the diagnosis and treatment of } 2019 \\
\text { novel coronavirus (2019-nCoV) infected pneumonia (standard version). Mil Med Res. 2020;7(1):4. } \\
\text { Published } 2020 \text { Feb 6. doi:10.1186/s40779-020-0233-6 }\end{array}$ \\
\hline USA & $91 \%$ & $\begin{array}{l}\text { Poston JT, Patel BK, Davis AM. Management of Critically Ill Adults With COVID-19. JAMA. } \\
\text { Published online March 26, 2020. doi:10.1001/jama.2020.4914 }\end{array}$ \\
\hline
\end{tabular}


medRxiv preprint doi: https://doi.org/10.1101/2020.07.03.20145763; this version posted July 4,2020 . The copyright holder for this preprint (which was not certified by peer review) is the author/funder, who has granted medRxiv a license to display the preprint in perpetuity.

It is made available under a CC-BY 4.0 International license .

\begin{tabular}{|c|c|c|}
\hline & $\begin{array}{l}\text { Target } \\
\text { O2 } \\
\text { Sats }\end{array}$ & $\begin{array}{l}\text { Link to National Guidelines } \\
\text { All viewed between 18th May } 2020 \text { and 6th June } 2020\end{array}$ \\
\hline Spain & $90 \%$ & $\begin{array}{l}\text { SOCIEDAD ESPAÑOLA DE NEUMOLOGIIA Y CIRUGÍA TORÁCICA } \\
\text { FISIOTERAPIA RESPIRATORIA EN EL MANEJO DEL PACIENTE CON COVID-19: } \\
\text { RECOMENDACIONES GENERALES } \\
\text { Spain - http://svmefr.com/wp-content/uploads/2020/03/COVID19-SEPAR-26_03_20.pdfhttp:// } \\
\text { svmefr.com/wp-content/uploads/2020/03/COVID19-SEPAR-26_03_20.pdf }\end{array}$ \\
\hline Mexico & $90 \%$ & $\begin{array}{l}\text { Government of Mexico } \\
\text { https://coronavirus.gob.mx/wp-content/uploads/2020/04/ } \\
\text { Flujograma_Atencion_Primer_Nivel_13042020.pdf }\end{array}$ \\
\hline Sweden & $90 \%$ & $\begin{array}{l}\text { Drug Therapeutic Committee and the Health and Medical Care Administration of the Stockholm } \\
\text { County Council, Sweden } \\
\text { https://janusinfo.se/behandling/akutinternmedicin/infektionssjukdomar/infektionssjukdomar/ } \\
\text { covid19infektion.5.5d5ae8ba1719cea8d541290e.html\#h-Skyddsutrustninginomsjukvarden }\end{array}$ \\
\hline Russia & $93 \%$ & $\begin{array}{l}\text { Ministry of Health } \\
\text { ПРОФИЛАКТИКА, } \\
\text { ДИАГНОСТИКА И ЛЕЧЕНИЕ НОВОЙ КОРОНАВИРУСНОЙ ИНФЕКЦИИ } \\
\underline{\text { https://static-1.rosminzdrav.ru/system/attachments/attaches/000/050/116/original// }} \\
\underline{28042020 \_ \text {MR_COVID-19_v6.pdf }}\end{array}$ \\
\hline
\end{tabular}

\section{Supplementary Table 1. Target oxygen saturations with links to national guidelines.}


medRxiv preprint doi: https://doi.org/10.1101/2020.07.03.20145763; this version posted July 4, 2020. The copyright holder for this preprint (which was not certified by peer review) is the author/funder, who has granted medRxiv a license to display the preprint in perpetuity.

It is made available under a CC-BY 4.0 International license. 


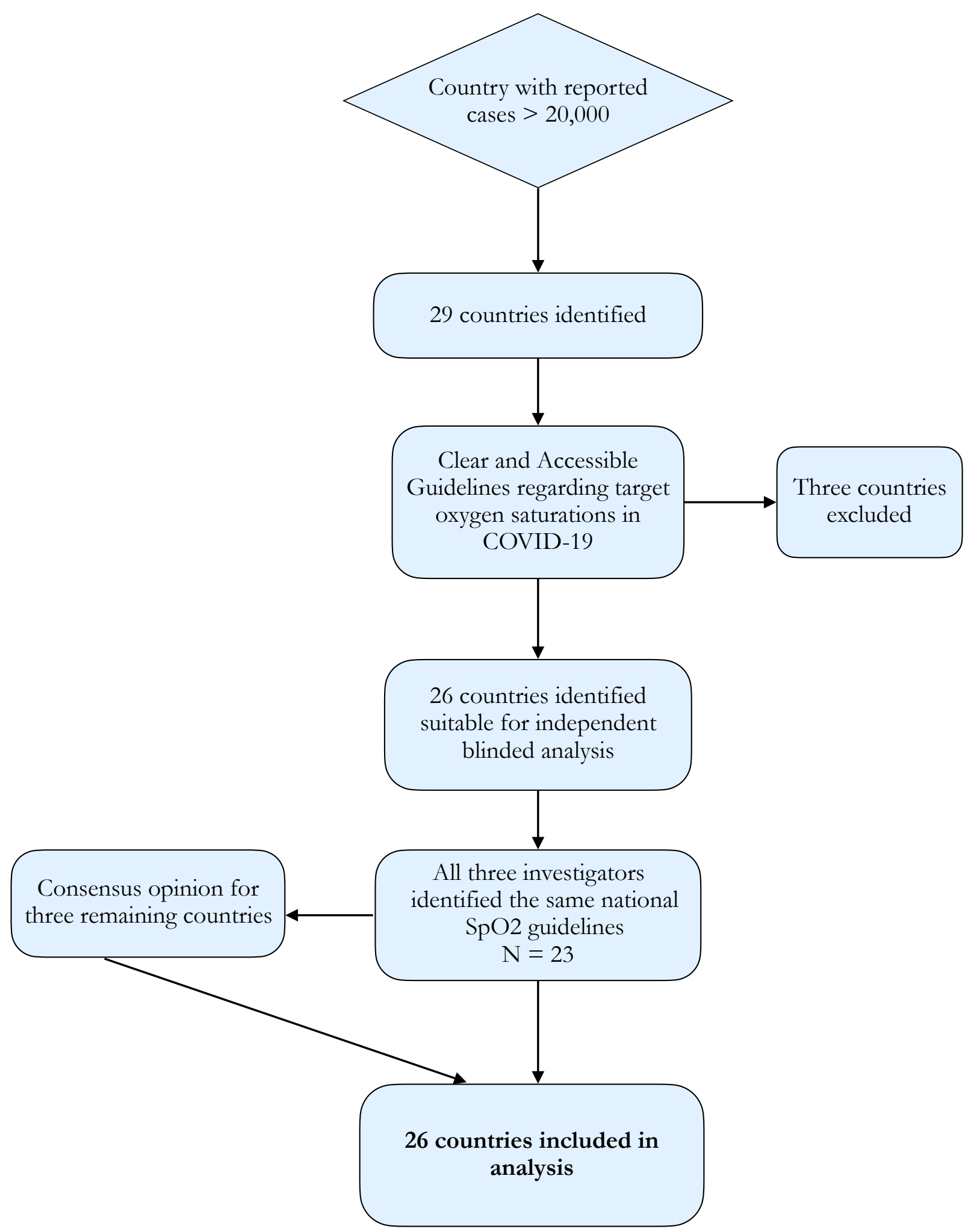

